This document was prepared in conjunction with work accomplished under Contract No. DE-AC09-96SR18500 with the U. S. Department of Energy.

\title{
DISCLAIMER
}

This report was prepared as an account of work sponsored by an agency of the United States Government. Neither the United States Government nor any agency thereof, nor any of their employees, nor any of their contractors, subcontractors or their employees, makes any warranty, express or implied, or assumes any legal liability or responsibility for the accuracy, completeness, or any third party's use or the results of such use of any information, apparatus, product, or process disclosed, or represents that its use would not infringe privately owned rights. Reference herein to any specific commercial product, process, or service by trade name, trademark, manufacturer, or otherwise, does not necessarily constitute or imply its endorsement, recommendation, or favoring by the United States Government or any agency thereof or its contractors or subcontractors. The views and opinions of authors expressed herein do not necessarily state or reflect those of the United States Government or any agency thereof. 


\section{RESULTS FOR THE DWPF SLURRY MIX EVAPORATOR CONDENSATE TANK, OFF GAS CONDENSATE TANK, AND RECYCLE COLLECTION TANK SAMPLES (U)}

T.L. Fellinger

N.E. Bibler

December 21, 2004 
This page was intentionally left blank 
Key Words: $D W P F$, Acid Evaporator, SMECT, OGCT, RCT

Retention: Permanent

\section{RESULTS FOR THE DWPF SLURRY MIX EVAPORATOR CONDENSATE TANK, OFF GAS CONDENSATE TANK, AND RECYCLE COLLECTION TANK SAMPLES (U)}

T.L. Fellinger
N.E. Bibler

December 21, 2004 
This page was intentionally left blank 


\section{EXECUTIVE SUMMARY}

The Defense Waste Processing Facility (DWPF) currently generates approximately 1.4 million gallons of recycle water per year during Sludge-Only operations. DWPF has minimized condensate generation to 1.4 million gallons by not operating the Steam Atomized Scrubbers (SASs) for the melter off gas system. By not operating the SASs, DWPF has reduced the total volume by $\sim 800,000$ gallons of condensate per year. Currently, the recycle stream is sent to back to the Tank Farm and processed through the $2 \mathrm{H}$ Evaporator system. To alleviate the load on the $2 \mathrm{H}$ Evaporator system, an acid evaporator design is being considered as an alternate processing and/or concentration method for the DWPF recycle stream. In order to support this alternate processing option, the DWPF has requested that the chemical and radionuclide compositions of the Off Gas Condensate Tank (OGCT), Slurry Mix Evaporator Condensate Tank (SMECT), Recycle Collection Tank (RCT), and the Decontamination Waste Treatment Tank (DWTT) be determined as a part of the process development work for the acid evaporator design. Samples have been retrieved from the OGCT, RCT, and SMECT and have been sent to the Savannah River National Laboratory (SRNL) for this characterization. The DWTT samples have been recently shipped to SRNL. The results for the DWTT samples will be issued at later date. Below is a summary of the observations, conclusions and recommendations for the OGCT, RCT, and SMECT samples.

\section{Observations and Conclusions:}

- The OGCT and RCT samples had visible brown solids, and the SMECT samples had no visible solids. The solids in the OGCT sample appeared to be made up of fine particulates and settled very slowly when agitation of the sample was stopped. The solids in the RCT sample appeared to be fine as well, but settled quickly.

- The dried weight percent total solids (dried at $110^{\circ} \mathrm{C}$ ) for the OGCT and SMECT samples were very low; 0.44 and $<1 \mathrm{E}-03$ weight percent, respectively. The dried weight percent total solids for the RCT sample were also low; 1.88 weight percent.

- The results for the weight percent dissolved solids for the OGCT and SMECT samples indicate that there were no dissolved solids. For the OGCT sample, the total solids are considered all insoluble solids.

- The dried weight percent dissolved solids for the RCT sample were 1.73 weight percent. In the case of the RCT sample vs. the OGCT sample, the majority of solids are soluble vs. insoluble.

- The pH of the OGCT, RCT, and SMECT samples were measured and found to be 2.3, 12.6, and 1.4 , respectively.

- The major elements found in the dried solids of the OGCT sample were Fe, Si, $\mathrm{Na}, \mathrm{Mn}, \mathrm{Al}$, and $\mathrm{U}$. This is consistent with the results previously published by C.M. Jantzen ${ }^{1}$ for a Scaled Glass Melter Off-Gas Condensate Tank sample.

- The composition of the OGCT should be dependent on the feed being fed to the melter, however for this sample the relative composition only agreed for $\mathrm{Al}$ and $\mathrm{Fe}$. The difference seen in the relative amounts of the elements reported for the OGCT sample could be due to spinels being carried from the melter plenum as observed in the C.M. Jantzen sample. Scanning Electron Microscopy (SEM) was not performed to confirm this conclusion for the OGCT sample. 
- The major elements found in the dried solids of the RCT sample were Na, Fe, Al, U, Si, and Mn. The relative composition for the RCT agrees reasonably well with the relative composition of Sludge Batch 3. This agreement suggests that the primary component in this RCT sample is indeed due to SB3 sludge.

- The radioactive data for the OGCT and RCT samples agree well, upon converting the data to a micro-curie per milliliter slurry basis. This suggests that the radioactivity in this RCT sample is due to the contribution from the OGCT

- The major elements found in the SMECT samples were Si, Hg, Al, Na, and U. Since the SMECT receives condensate from the SRAT and SME vessels, it is expected that minor amounts of sludge components such as $\mathrm{Al}, \mathrm{Na}$, and $\mathrm{U}$ could be entrained in the condensate. The amount of Si present in these samples is probably from the antifoam additions and the $\mathrm{Hg}$ is from the steam stripping operations during the SRAT cycle.

Recommendations:

- Since the composition of the samples is dependant on the incoming streams to the individual tanks, they are likely to change over time depending on the Sludge Batch being processed. It is recommended that this data be treated as a snapshot in time, and the composition provided for each tank be bounded for the upcoming experimental work and computer modeling.

- Complete the analyses for the DWTT samples on hand, and document the composition. 


\section{TABLE OF CONTENTS}

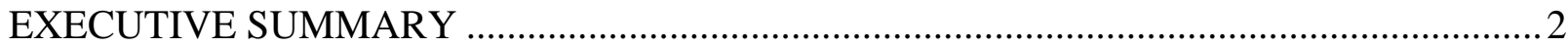

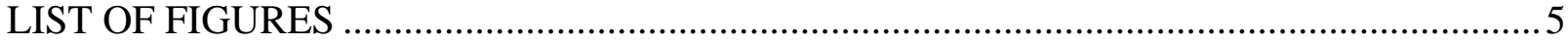

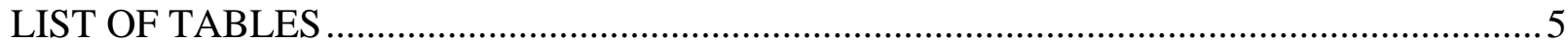

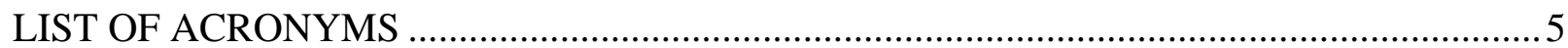

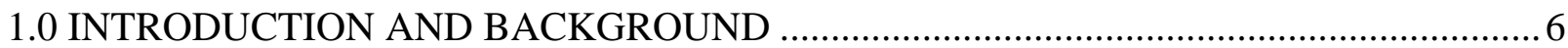

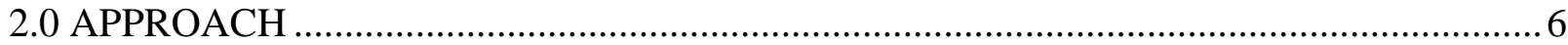

2.1 Characterization of the SMECT, OGCT, and RCT Samples.......................................... 6

2.2 Brief Description of Analyses Performed for the SMECT, OGCT and RCT ...................... 7

3.0 RESULTS FOR THE OGCT, RCT, AND SMECT SAMPLES .......................................9

3.1 Summary of Analytical Data Obtained for the OGCT, RCT, and SMECT Samples ............9

3.2 Comparison of the SMECT, OGCT, and RCT Samples to the March 2004 Sludge Batch 3

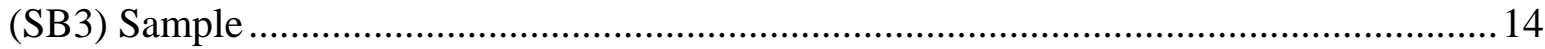

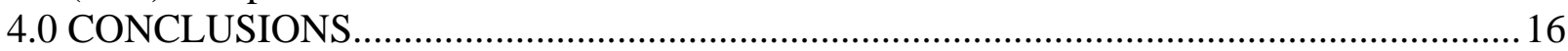

5.0 RECOMMENDATIONS/PATH FORWARD ........................................................... 17

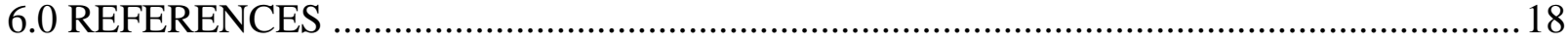

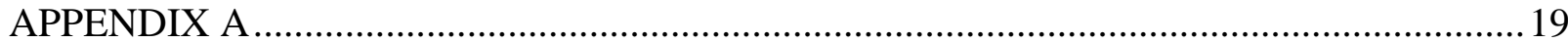




\section{LIST OF FIGURES}

Figure A - 1 Titration Curve for the OGCT Samples .......................................................... 23

Figure A - 2 Titration Curve for the RCT Samples ......................................................... 24

\section{LIST OF TABLES}

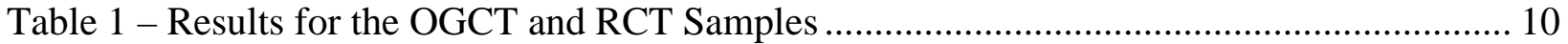

Table 2 - Results for the SMECT Samples .......................................................................... 13

Table A-1 - Averages, Standard Deviations and Percent Relative Standard Deviations for the

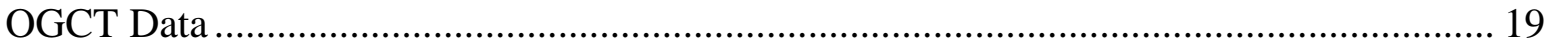

Table A-2 - Averages, Standard Deviations and Percent Relative Standard Deviations for the

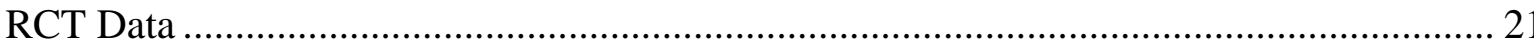

\section{LIST OF ACRONYMS}

DWPF - Defense Waste Processing Facility

DWTT - Decontamination Waste Treatment Tank

ICP-ES - Inductively Coupled Plasma Emission Spectrometer

ITS - Immobilization Technology Section

OGCT- Off Gas Condensate Tank

RCT- Recycle Collection Tank

SME- Slurry Mix Evaporator

SMECT - Slurry Mix Evaporator Condensate Tank

SRAT - Sludge Receipt and Adjustment Tank 


\subsection{INTRODUCTION AND BACKGROUND}

The Defense Waste Processing Facility (DWPF) typically generates approximately 1.4 million gallons of recycle water per year during Sludge-Only operations ${ }^{2}$. The recycle water stream is neutralized in DWPF prior to being sent back to the Tank Farm for processing through the $2 \mathrm{H}$ Evaporator system.

Due to recent Tank Farm space limitations and previous outages in the $2 \mathrm{H}$ evaporator system (due to the alumina-silicate deposits ${ }^{3}$ ), a Savannah River Site (SRS) needs statement was issued to determine if there were alternative processing and/or concentration methods for the DWPF recycle stream ${ }^{4}$. In January of 2002, a study was completed to determine the feasibility of operating of an acid evaporator in the DWPF ${ }^{2}$. The conclusions from this study showed that the operation of an acid evaporator in the DWPF was feasible. However, these conclusions were based on limited compositional information concerning the streams that make up the recycle water and computer simulations. Several recommendations were made in the report documenting the findings of the study ${ }^{2}$. These recommendations are summarized in the bullets listed below.

Samples of the individual streams that make-up the recycle stream should be taken and analyzed for chemical and radionuclide composition.

Experiments should be performed with simulated/actual recycle to determine how extensively the solution can be evaporated.

Use the compositional information and the results from the experimental work to predict/confirm computer simulations.

In order to address the recommendations for the operation of an acid evaporator in the DWPF, a Technical Task Request (TTR) ${ }^{5}$ was issued by DWPF requesting that the Savannah River National Lab (SRNL) perform several process development tasks ${ }^{6}$.

To complete the characterization, several samples were pulled from the Off Gas Condensate Tank (OGCT), Slurry Mix Evaporator Condensate Tank (SMECT), and Recycle Collection Tank (RCT) and sent to SRNL. The samples were placed into the Shielded Cells, sampled and analyzed. This report summarizes the chemical and radionuclide results obtained for the OGCT, SMECT, and RCT. Samples of the Decontamination Waste Treatment Tank (DWTT) were recently received and will be documented at a later date.

\subsection{APPROACH}

\subsection{Characterization of the SMECT, OGCT, and RCT Samples}

Eight samples (maximum volume of each bottle is $125 \mathrm{~mL}$ ) were taken from the SMECT, OGCT, and RCT at DWPF. The samples were transported to SRNL for characterization. Upon receipt of the SMECT, OGCT, and RCT samples, the samples were placed into the Shielded Cells, mixed and poured into individually labeled 1 liter bottles for each tank, respectively. The OGCT and RCT had visible brown solids and the SMECT samples had no visible solids. The solids in the OGCT sample appeared to be made up of fine particulates and settled very slowly. The solids in the RCT appeared to be fine as well, but settled quickly. Mixed samples of the OGCT and RCT were removed from their respective bottles and submitted for analyses to obtain the following data: 
$-\mathrm{pH}$

- Weight percent total solids

- Weight percent dissolved solids in the supernate (if solids were present)

- Calculation for the insoluble and the soluble solids (if solids were present)

- Density measurements for slurry (if solids were present) and supernate

- Inductively Coupled Plasma Emission Spectroscopy (ICP-ES) results

- Inductively Coupled Plasma Mass Spectroscopy (ICP-MS) results

- $\quad$ Cold Vapor Hg, Se, and As results

- Counting Data (Gamma Scan, Total Alpha, and Total Beta)

- $\quad$ Equivalents of Acid or Base required to obtain $\mathrm{pH}$ of 7

- $\quad$ Ion Chromatography (IC) results for anions and ammonium

- $\quad$ Total Carbon (TC), Total Inorganic Carbon (TIC), and Total Organic Carbon (TOC)

- $\quad$ Particle Size (if solids were present)

It should be noted that previously received SMECT samples were used to obtain missing data that were requested above $(\mathrm{pH}, \mathrm{Eq} / \mathrm{L}$, and TC/TIC/TOC). The remaining required data for the SMECT samples was previously documented and can be found in report WSRC-TR-2004-00575 ${ }^{7}$. A brief description of the analytical methods is provided in Section 2.2.

\subsection{Brief Description of Analyses Performed for the SMECT, OGCT and RCT}

\section{pH Measurements}

To perform the $\mathrm{pH}$ measurements, a portion of each sample was removed and checked with an in-cell $\mathrm{pH}$ probe. The probe is first standardized with buffer solutions at a $\mathrm{pH}$ of 10 and 7 . The probe is then checked with a $\mathrm{pH} 4$ buffer solution. Once the $\mathrm{pH}$ probe has been checked out, the $\mathrm{pH}$ measurement of the samples are completed. After the completion of the sample measurements, the $\mathrm{pH}$ probe is then checked again with the buffer solutions to determine if the $\mathrm{pH}$ probe drifted away from the initial standardization.

\section{Weight Percent Solids Measurements}

To perform the weight percent solids measurement for the sludge slurry, mixed samples of sludge slurry were pipetted out of the one-liter container and placed into labeled beakers. These beakers are weighed and then placed into a drying oven at $115^{\circ} \mathrm{C}$ overnight. Samples of a $\mathrm{NaCl}$ solution with a known weight percent total solids are also weighed and dried (in labeled beakers) along with the sludge slurry samples to check the accuracy and precision of the method. All of the samples are removed from the oven and allowed to cool for $\sim 5$ minutes before they are weighed. Once a constant weight is obtained, the measurement is considered complete.

To obtain the supernate for the weight percent solids measurement, a mixed sample of the combined sludge slurry is filtered through a $0.45 \mu$ Nalgene ${ }^{\circledR}$ filter resulting in a clear supernate. The same procedure used for the sludge slurry is followed for the supernate.

\section{Calculation of Insoluble Solids and Soluble Solids for the Slurry Sample}

Once the average for the total weight percent solids of the sludge slurry and the average weight percent dissolved solids in the supernate values are determined, the soluble and insoluble weight percent solids were calculated. These values are calculated by using the following equations ${ }^{8}$ :

Equation 1: $\quad \mathrm{W}_{\mathrm{is}}=\left(\mathrm{W}_{\mathrm{ts}}-\mathrm{W}_{\mathrm{ds}}\right) /\left(1-\mathrm{W}_{\mathrm{ds}}\right)$

Equation 2: $\quad \mathrm{W}_{\mathrm{ss}}=\mathrm{W}_{\mathrm{ts}}-\mathrm{W}_{\mathrm{is}}$ 
$\mathrm{W}_{\mathrm{ds}}$ - Weight fraction of dissolved solids (weight of dissolved solids/weight of supernate)

$\mathrm{W}_{\mathrm{ts}}$ - Weight fraction of total solids (weight of total solids/weight of sludge slurry)

$\mathrm{W}_{\mathrm{is}}$ - Weight fraction of insoluble solids (weight of insoluble solids/weight of sludge slurry)

$\mathrm{W}_{\mathrm{ss}}$ - Weight fraction of soluble solids (weight dissolved solids/weight of sludge slurry)

\section{Density Determinations for the Sludge Slurry and Supernate}

Density measurements for the sludge slurry and supernate are completed remotely in the Shielded Cells Facility by using heat sealed pipette tips. The pipette tips are first sealed and then calibrated with water to obtain the volume. After determining the volume, density measurements are completed for the sludge slurry and supernate. The sealed pipette tip is first weighed and then a mixed sample of sludge slurry is pipetted into the sealed pipette tip. The sealed pipette tip containing the sludge slurry sample is weighed and a density calculated. The same protocol is used for the supernate samples. The supernate sample is obtained by filtering a portion of the sludge slurry.

\section{$\underline{\text { ICP-ES, ICP-MS, Cold Vapor Hg, Se, As, Gamma Scan, Total Alpha, and Total Beta Results }}$}

The ICP-ES method provides the data for the nonradioactive analytes plus total U. The ICP-MS method provides the data for fission product and actinide concentrations of the samples. The Cold Vapor Hg, Se, and As methods provide the concentrations of $\mathrm{Hg}$, Se, and As, respectively. The gamma scan provides the concentrations of the major gamma emitters present in the samples, such as Co-60, Eu-154, etc. The total alpha and total beta methods provide the total activity for alpha and beta emitters in the sample.

If the samples contained solids they were dissolved per the dissolution techniques, described in the paragraph below. If the samples had no solids, three portions of the sample were removed from the Shielded Cells and analyzed per the requested methods.

To dissolve the sludge slurry, three portions of a mixed sample were taken and dried overnight in a drying oven at $115^{\circ} \mathrm{C}$. This dried sludge slurry was then dissolved by the Aqua Regia and Peroxide Fusion methods along with appropriate standards and blanks to check the dissolutions and the analytical methods. After performing the dissolution methods on the sludge slurry, a portion of the dissolved samples were removed from the Shielded Cells Facility. These dissolved samples were sent to Analytical Development Section (ADS) Sample Receiving for analyses to be performed by ADS.

\section{Equivalents of Acid or Base Required to Obtain a $\mathrm{pH}$ of 7}

To obtain the amount of acid or base required to obtain a $\mathrm{pH}$ of 7 for the samples, titrations are completed on two portions ( $10 \mathrm{~g}$ each) of each mixed sample. The first step in the procedure was to weigh each individual portion of the sample. The next step was to add a known volume of $0.1 \mathrm{~N} \mathrm{HCl}$ or $0.1 \mathrm{~N} \mathrm{NaOH}$ to the sample depending on the starting $\mathrm{pH}$. The sample is then mixed, and a $\mathrm{pH}$ recorded once the readout from the $\mathrm{pH}$ probe stabilized. The volume of acid or base is also recorded after each addition to the sample. The titration was considered complete once the $\mathrm{pH}$ of the sample is below a $\mathrm{pH}$ of 5.0. This procedure was repeated on the remaining portion of the sample.

Ion Chromatography (IC) Results for Anions and Ammonium

If the samples had no solids, three portions of the sample are taken and analyzed per the requested methods. If the samples contained solids, a mixed sample of the slurry was filtered through a $0.45 \mu$ Nalgene ${ }^{\circledR}$ filter resulting in a clear supernate. These samples were diluted, removed, and analyzed per the requested methods. 
Total Carbon (TC), Total Inorganic Carbon (TIC), and Total Organic Carbon (TOC)

To obtain the TC, TIC, and TOC concentrations of the samples, a few drops of the mixed samples were diluted and placed into shielded bottles. Shielded bottles were used for these samples due to the radioactivity of the sludge slurry. These samples were removed from the Shielded Cells and submitted to ADS for analysis.

\section{Particle Size}

This analysis was not complete for the OGCT and RCT samples, due to the radioactivity and amount of sample required to perform the analysis. The SMECT samples were submitted and the results are reported in Section 3.0 of this report.

\subsection{RESULTS FOR THE OGCT, RCT, AND SMECT SAMPLES}

\subsection{Summary of Analytical Data Obtained for the OGCT, RCT, and SMECT Samples}

As mentioned in Sections 2.1 and 2.2, analyses for the SMECT, OGCT, and RCT were completed. Table 1 provides a summary of the data collected for the OGCT and RCT samples. Table 2 provides a summary of the data collected for two samples of the SMECT. Since the SMECT data has been discussed previously in WSRC-TR-2004-00575, a table with footnotes and a brief overview of the data will be provided (See Section 2.1). Unless otherwise denoted in the Table 1, the values presented in Table 1 are the average of three values. The SMECT data in Table 2 are results of a single analysis for each analyte. Appendix A contains two tables with the averages, standard deviations and percent relative standard deviations for the data presented in Table 1. Appendix A also contains the titration curves for the OGCT and RCT samples. 
WSRC-TR-2004-00577

Revision 0

Table 1 - Results for the OGCT and RCT Samples

\begin{tabular}{|c|c|c|c|}
\hline Category & Analyte & OGCT Results & RCT Results \\
\hline \multirow[t]{6}{*}{$\begin{array}{c}\text { Wt.\% Solids and } \\
\text { Density } \\
\end{array}$} & $\begin{array}{l}\text { Wt.\% Dissolved Solids of } \\
\text { Supernate }\end{array}$ & $0^{*}$ & 1.73 \\
\hline & $\begin{array}{l}\text { Wt. \% Total Solids of } \\
\text { Slurry }\end{array}$ & $0.44^{\mathrm{a}}$ & 1.88 \\
\hline & Wt.\% Insoluble Solids & 0.44 & 0.15 \\
\hline & Wt.\% Soluble Solids & 0 & 1.73 \\
\hline & Slurry Density, g/mL & 1.02 & 1.02 \\
\hline & Supernate Density, g/mL & 0.99 & 1.01 \\
\hline \multirow[t]{4}{*}{ Wet Chem } & Total Carbon, mg/L & $<102$ & 191 \\
\hline & $\begin{array}{c}\text { Total Organic Carbon, } \\
\text { mg/L }\end{array}$ & $<102$ & 143 \\
\hline & $\begin{array}{c}\text { Total Inorganic Carbon, } \\
\text { mg/L }\end{array}$ & $<102$ & $<48$ \\
\hline & Particle Size & N.M. & N.M. \\
\hline \multirow[t]{2}{*}{ Titration } & $\begin{array}{l}\begin{array}{l}\text { Equivalents Required for } \\
\mathrm{pH}=7\end{array} \\
\end{array}$ & 1.99E-02 Eq/L & 7.80E-02 Eq/L \\
\hline & $\mathrm{pH}$ & 2.3 & 12.6 \\
\hline \multirow[t]{8}{*}{$\begin{array}{c}\text { Anions (mg/L of } \\
\text { supernate) }\end{array}$} & Chloride & $5 \mathrm{E} 00^{\mathrm{f}}$ & $<3 \mathrm{E} 00$ \\
\hline & Formate & $<1.4 \mathrm{E} 01^{\mathrm{f}}$ & $3.1 \mathrm{E} 02^{\mathrm{g}}$ \\
\hline & Fluoride & $1.9 \mathrm{E} 01^{\mathrm{f}}$ & $<3 \mathrm{E} 00^{\mathrm{g}}$ \\
\hline & Nitrate & $1.59 \mathrm{E} 03^{\mathrm{f}}$ & $4.74 \mathrm{E} 03^{g}$ \\
\hline & Nitrite & $<1.4 \mathrm{E} 01^{\mathrm{f}}$ & $4.08 \mathrm{E} 03^{g}$ \\
\hline & Oxalate & $<1.4 \mathrm{E} 01^{\mathrm{f}}$ & $<1.4 \mathrm{E} 02^{\mathrm{g}}$ \\
\hline & Phosphate & $<1.4 \mathrm{E} 01^{\mathrm{f}}$ & $<1.4 \mathrm{E} 02^{\mathrm{g}}$ \\
\hline & Sulfate & $6.1 \mathrm{E} 01^{\mathrm{f}}$ & $4.8 \mathrm{E} 01^{\mathrm{g}}$ \\
\hline $\begin{array}{c}\text { IC-Cations (mg/L of } \\
\text { supernate) }\end{array}$ & Ammonium & $1.39 \mathrm{E} 00$ & $<1 \mathrm{E} 01$ \\
\hline \multirow[t]{4}{*}{$\begin{array}{c}\text { AA Results (wt.\% dried } \\
\text { sludge solids) }\end{array}$} & $\mathrm{Hg}$ & 3.64E-02 & 8.58E-02 \\
\hline & As & $<6 \mathrm{E}-03$ & $<3 \mathrm{E}-03$ \\
\hline & $\mathrm{K}$ & $1.80 \mathrm{E}-02$ & 3.68E-02 \\
\hline & Se & $<6 \mathrm{E}-03$ & $<3 \mathrm{E}-03$ \\
\hline \multirow[t]{21}{*}{$\begin{array}{c}\text { ICP-ES (wt.\% dried } \\
\text { sludge solids) }\end{array}$} & Ag & $1.34 \mathrm{E}-02$ & 2.94E-03 \\
\hline & $\mathrm{Al}$ & $2.36 \mathrm{E} 00$ & 6.73E-01 \\
\hline & $\mathrm{B}$ & 5.03E-01 & 4.81E-02 \\
\hline & $\mathrm{Ba}$ & 3.08E-02 & 5.53E-03 \\
\hline & $\mathrm{Be}$ & 2.85E-04 & 4.15E-05 \\
\hline & $\mathrm{Ca}$ & 5.13E-01 & 3.0E-01 \\
\hline & $\mathrm{Cd}$ & $3.24 \mathrm{E}-01$ & 3.14E-02 \\
\hline & $\mathrm{Ce}$ & 4.84E-02 & $1.42 \mathrm{E}-02$ \\
\hline & $\mathrm{Cr}$ & 8.29E-02 & 3.09E-02 \\
\hline & $\mathrm{Cu}$ & $2.74 \mathrm{E}-02$ & 3.11E-03 \\
\hline & $\mathrm{Fe}$ & $2.26 \mathrm{E} 01$ & $1.85 \mathrm{E} 00$ \\
\hline & $\mathrm{Gd}$ & 2.02E-02 & 4.98E-03 \\
\hline & $\mathrm{La}$ & 1.75E-02 & $5.16 \mathrm{E}-03$ \\
\hline & $\mathrm{Li}$ & $2.21 \mathrm{E}-01$ & $1.04 \mathrm{E}-01$ \\
\hline & $\mathrm{Mg}$ & $1.27 \mathrm{E} 00$ & 1.70E-01 \\
\hline & $\mathrm{Mn}$ & 2.69E00 & 3.79E-01 \\
\hline & Mo & 7.76E-02 & 9.71E-03 \\
\hline & $\mathrm{Na}$ & $3.71 \mathrm{E} 00$ & 2.71E01 \\
\hline & $\mathrm{Ni}$ & $1.18 \mathrm{E} 00$ & $1.04 \mathrm{E}-01$ \\
\hline & $\mathrm{P}$ & 3.35E-01 & 4.97E-02 \\
\hline & $\mathrm{Pb}$ & 4.16E-02 & $<2 \mathrm{E}-02$ \\
\hline
\end{tabular}


WSRC-TR-2004-00577

Revision 0

\begin{tabular}{|c|c|c|c|}
\hline Category & Analyte & OGCT Results & RCT Results \\
\hline & $\mathrm{S}$ & 4.73E-01 & 9.11E-02 \\
\hline & $\mathrm{Sb}$ & $7.51 \mathrm{E}-02$ & $8.40 \mathrm{E}-03$ \\
\hline & $\mathrm{Si}$ & $3.74 \mathrm{E} 00^{\mathrm{b}}$ & 4.45E-01 \\
\hline & Sn & $1.19 \mathrm{E}-01$ & $1.47 \mathrm{E}-02$ \\
\hline & $\mathrm{Sr}$ & 1.33E-01 & 4.43E-02 \\
\hline & $\mathrm{Ti}$ & $1.55 \mathrm{E}-02$ & 1.96E-03 \\
\hline & $\mathrm{U}$ & 1.52E00 & 5.73E-01 \\
\hline & $\mathrm{V}$ & $<3.0 \mathrm{E}-02$ & $<4.0 \mathrm{E}-03$ \\
\hline & $\mathrm{Zn}$ & 3.82E-02 & 4.85E-03 \\
\hline & $\mathrm{Zr}$ & $9.48 \mathrm{E}-02$ & $8.44 \mathrm{E}-03$ \\
\hline \multirow[t]{11}{*}{$\begin{array}{l}\text { ICP-MS Results (wt.\% } \\
\text { dried sludge solids) }\end{array}$} & $\mathrm{Ru}^{\mathrm{c}}$ & $3.42 \mathrm{E}-02$ & $1.77 \mathrm{E}-03$ \\
\hline & $\mathrm{Rh}^{\mathrm{C}}$ & 6.19E-03 & 3.45E-04 \\
\hline & $\mathrm{Pd}^{\mathrm{C}}$ & 1.23E-03 & 5.67E-05 \\
\hline & $\mathrm{Ag}^{\mathrm{C}}$ & $9.73 \mathrm{E}-03$ & $5.76 \mathrm{E}-04$ \\
\hline & $\mathrm{Cd}^{\mathrm{C}}$ & $3.50 \mathrm{E}-01$ & $1.51 \mathrm{E}-02$ \\
\hline & $\mathrm{U}^{\mathrm{C}}$ & 1.32E00 & 3.11E-01 \\
\hline & Pu-239 & $1.46 \mathrm{E}-02$ & 1.03E-03 \\
\hline & $\mathrm{Pu}-240$ & $1.36 \mathrm{E}-03$ & 9.42E-05 \\
\hline & $\mathrm{Pu}-242$ & 6.92E-05 & - \\
\hline & Tc-99 & $2.83 \mathrm{E}-03$ & $1.59 \mathrm{E}-04$ \\
\hline & La-139 & 1.42E-02 & $1.28 \mathrm{E}-03$ \\
\hline \multirow[t]{10}{*}{$\begin{array}{c}\text { Radioactivity ( } \mu \mathrm{Ci} / \mathrm{g} \text { of } \\
\text { dried sludge solids) }\end{array}$} & Total Alpha & 9.65E01 & 2.59E01 \\
\hline & Total Beta & $4.20 \mathrm{E} 03$ & 1.34E03 \\
\hline & Total Gamma $^{\mathrm{d}}$ & $1.84 \mathrm{E} 02$ & 5.96E01 \\
\hline & Co-60 & $1.95 \mathrm{E} 00$ & 2.09E-01 \\
\hline & Ru-106 & $<3 \mathrm{E} 00$ & $<1 \mathrm{E} 00$ \\
\hline & Sb-125 & $<3 \mathrm{E} 00$ & $<1 \mathrm{E}-01$ \\
\hline & Cs-137 & 1.62E02 & 5.41E01 \\
\hline & Eu-154 & $3.06 \mathrm{E} 00$ & 9.38E-01 \\
\hline & Am-241 & $1.06 \mathrm{E} 01$ & $1.95 \mathrm{E} 00$ \\
\hline & $\begin{array}{c}\text { Total beta-gamma, } \\
\mu \mathrm{Ci} / \mathrm{g}^{\mathrm{e}}\end{array}$ & 4.38E03 & $1.40 \mathrm{E} 03$ \\
\hline
\end{tabular}

* Three measurements were completed. The results indicate that there were no soluble solids per a three place balance.

a Due to the low amount of solids present in the OGCT sample, one large sample was dried for weight percent solids. This material was used for the dissolutions.

${ }^{\mathrm{b}}$ Average of two values for Si.

${ }^{\mathrm{c}}$ More than one isotope was used to calculate the weight percent. For example, masses 107 and 109 were added together for the Ag.

${ }^{d}$ To obtain the total gamma, the gamma emitters were added together

e To obtain the total beta/gamma, the total beta reported for the sludge and the gamma emitters were added together.

${ }^{\mathrm{f}}$ To convert the data from a supernate basis to a slurry basis multiply the value by $1.029 \mathrm{~mL}$ of supernate / $\mathrm{mL}$ of slurry. Calculation based on wt.\% solids and density information from the sample.

${ }^{g}$ To convert the data from a supernate basis to a slurry basis multiply the value by $1.003 \mathrm{~mL}$ of supernate / $\mathrm{mL}$ of slurry. Calculation based on wt.\% solids and density information from the sample.

N.M. - Not Measured

Based on the OGCT data presented in Table 1, the non-radioactive and radioactive compositions are indicative of a sludge distribution with a minor contribution from the frit components. Fe appears to be the dominant component followed by $\mathrm{Si}, \mathrm{Na}, \mathrm{Mn}, \mathrm{Al}$, and $\mathrm{U}$. No measurable solids were detected for the supernate and the concentration of the nitrate present in the supernate correlates to $\sim 0.02 \mathrm{~N}$ nitric acid solution which is in agreement with the $\mathrm{pH}$ of the sample. The sulfate present in the supernate (converted to slurry basis by multiplying concentration in supernate by a conversion factor of $1.029 \mathrm{~mL}$ of 
supernate/mL of slurry) of this sample also compares well with the total sulfur (once converted to sulfate) analyzed by ICP-ES from the dissolution solutions. Approximately $98 \%$ of the sulfate is soluble which is consistent with the $\mathrm{pH}$ of the sample. The natural abundances for $\mathrm{Ag}$ and $\mathrm{Cd}$ agree well with data generated from the ICP-MS. There are differences noted for the Ag and U when comparing the ICP-MS data to the ICP-ES data. It is recommended that the ICP-MS results for Ag and total U be used instead of the ICP-ES data. The ICP-MS has lower detection limits for these particular elements. The gamma scan results are also consistent with the results of others sludges, based on the fact that Co, Eu, and Am were detected. Since the Pu-238 and Sr-90 concentrations were not requested as a part of this task, the activity levels reported for the total alpha and total beta could not be cross checked for accuracy. Based on the acidity of the sample, no inorganic carbon should be present, and based on the IC results no organic carbon is expected. The TIC/TOC results for the OGCT sample support these conclusions.

Based on the RCT data presented in Table 1, the non-radioactive and radioactive compositions are also indicative of a sludge distribution with a minor contribution from the frit components. The $\mathrm{Na}$ is the dominant component in this sample followed by Fe, $\mathrm{U}, \mathrm{Si}$, and $\mathrm{Mn}$. This distribution is different from the OGCT samples. The differences noted between the OGCT and the RCT samples can be explained by the contributions of the SMECT and the DWPF Analytical Lab stream (this contribution is small in comparison with the SMECT). The high Na concentration in this sample is due to the neutralization of the acidic streams (SMECT and OGCT) in the RCT with $\mathrm{NaOH}$ and $\mathrm{NaNO}_{2}$ is added as an inhibiter. The addition of these components is required to meet Tank Farm requirements for transfer. The neutralization step explains the observed $\mathrm{pH}$ of this sample, the dissolved solids, and the concentrations of the nitrite reported in Table 1 for this sample. The sulfate present in the supernate (converted to slurry basis by multiplying concentration in supernate by a conversion factor of $1.003 \mathrm{~mL}$ of supernate/mL of slurry) of this sample also compares well with the total sulfur (once converted to sulfate) analyzed by ICP-ES from the dissolution solutions. Approximately $86 \%$ of the sulfate is soluble in this sample. It is possible that some of the sulfate was precipitated as sodium sulfate during the neutralization of the RCT contents. The natural abundances for Ag and Cd agree well with data generated from the ICP-MS. As discussed in the previous paragraph for the OGCT samples, it is recommended that the ICP-MS data for Ag and U be used instead of the ICP-ES data. The radioactive data for the OGCT and RCT samples agree well, upon converting the data to a micro-curie per milliliter slurry basis. This suggests that the radioactivity in this RCT sample is due to the contribution from the OGCT. Based on the chemical history of the streams coming into the RCT (acid streams), no inorganic carbon should be present. However, small amounts of organic carbon are expected in these samples (formate from the formic acid additions and carbon from the antifoam that is added during processing). The TIC/TOC results for the RCT sample support these conclusions. 
Table 2 - Results for the SMECT Samples ${ }^{\mathrm{a}}$

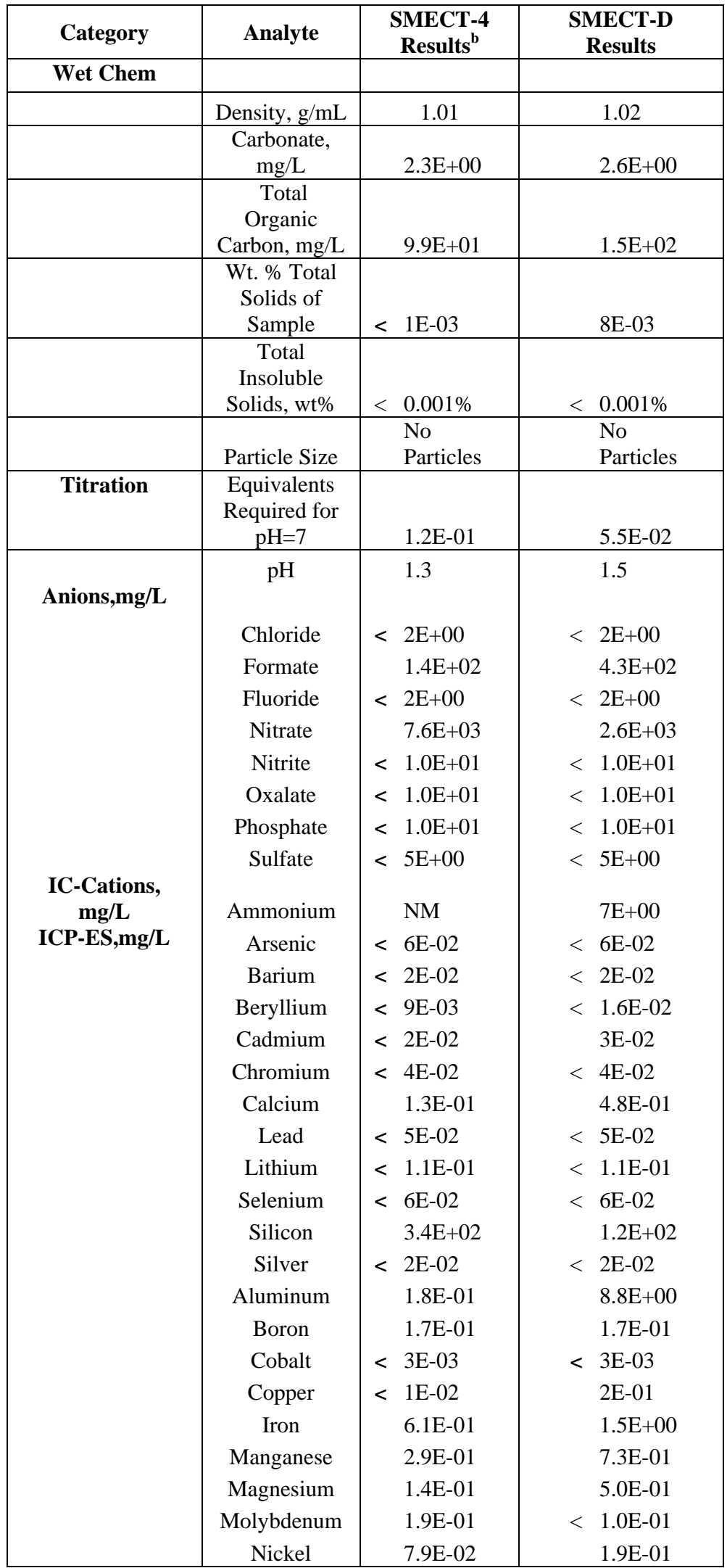


WSRC-TR-2004-00577

Revision 0

\begin{tabular}{|c|c|c|c|}
\hline Category & Analyte & $\begin{array}{c}\text { SMECT-4 } \\
\text { Results }\end{array}$ & $\begin{array}{c}\text { SMECT-D } \\
\text { Results }\end{array}$ \\
\hline \multirow{5}{*}{ Sodium } & $1.3 \mathrm{E}+00$ & $2.6 \mathrm{E}+00$ \\
& Tin & $8.5 \mathrm{E}-01$ & $<3.2 \mathrm{E}-01$ \\
& Titanium & $<1.7 \mathrm{E}-02$ & $<1.7 \mathrm{E}-02$ \\
& Potassium & $<9.3 \mathrm{E}+00$ & $<9.3 \mathrm{E}+00$ \\
& Strontium & $4.0 \mathrm{E}-02$ & $1.1 \mathrm{E}-01$ \\
& Uranium & $4.8 \mathrm{E}-01$ & $2.3 \mathrm{E}+00$ \\
AA, mg/L & Zinc & $<1 \mathrm{E}-02$ & $4.7 \mathrm{E}-01$ \\
Radioactivity, & Zirconium & $<2.9 \mathrm{E}-02$ & $<2.9 \mathrm{E}-02$ \\
& Mercury & $1.7 \mathrm{E}+02$ & $1.1 \mathrm{E}+02$ \\
& Total Alpha & $<1.5 \mathrm{E}+03$ & $3.4 \mathrm{E}+03$ \\
& Total Beta & $8.2 \mathrm{E}+04$ & $2.8 \mathrm{E}+05$ \\
& Total Gamma & $2.7 \mathrm{E}+03$ & $6.0 \mathrm{E}+03$ \\
& Co-60 & $1.3 \mathrm{E}+01$ & $3.0 \mathrm{E}+01$ \\
& Ru-106 & $<7.3 \mathrm{E}+00$ & $<1.2 \mathrm{E}+01$ \\
& Sb-125 & $<4.0 \mathrm{E}+00$ & $<.3 \mathrm{E}+00$ \\
& Cs-137 & $2.6 \mathrm{E}+03$ & $5.7 \mathrm{E}+03$ \\
& Eu-154 & $3.9 \mathrm{E}+01$ & $2.9 \mathrm{E}+02$ \\
& Total beta- & & \\
& gamma, & & \\
& pCi/mL & $8.5 \mathrm{E}+04$ & $2.7 \mathrm{E}+05$ \\
\hline
\end{tabular}

${ }^{\mathrm{a}}$ Results are from single analysis of each sample

${ }^{\mathrm{b}}$ SMECT-4 was a sample of SMECT Batch C described in Reference 7

Table 2 contains the results for two different SMECT samples previously analyzed by Bibler ${ }^{7}$. The units in this table are slightly different that that for the OGCT and RCT samples, because these samples are solutions and the OGCT and RCT samples are slurries. The SMECT samples had no solids versus the OGCT and RCT sample which had solids, hence the different units. The dominant components of the SMECT solutions are Si, Hg, Na, Fe, and U. Since the SMECT tank receives condensate from the SRAT and SME vessels, the source of the $\mathrm{Si}$ is probably from antifoam additions and the source of $\mathrm{Hg}$ is from the steam stripping of Hg during the SRAT cycle. The alpha, beta, and gamma activities of these SMECT samples are much lower than that reported for the OGCT and RCT samples. The anion data agrees with the $\mathrm{pH}$ recorded for the SMECT samples, indicating that this solution is mainly a nitric acid solution. The TOC data reported for these samples appears to be higher versus the formate concentrations reported. This could be due to the antifoam solution added during the SRAT and SME cycles.

\subsection{Comparison of the SMECT, OGCT, and RCT Samples to the March 2004 Sludge Batch 3 (SB3) Sample}

In order to compare the chemical composition of the samples to the current sludge batch composition, the ratio of several elements (both sludge and frit components) were taken to Fe. Fe was selected, because it is a main component of the sludge. Ratios were necessary for the comparison, because of the relative concentrations of elements reported for each of these samples. Table 3 contains the ratios for ten elements for the SMECT, OGCT, and RCT compared to the March 2004 SB3 sample ${ }^{9}$. The ratios for the elements that agreed with SB3 are bolded for comparison. 
WSRC-TR-2004-00577

Revision 0

Table 3 - Ratios of Elements to Fe for the SMECT, OGCT, and RCT Compared to the March 2004 SB3 Sample

\begin{tabular}{|c|c|c|c|c|}
\hline Elements & $\begin{array}{c}\text { SMECT Ratio } \\
\text { (Element:Fe) }\end{array}$ & $\begin{array}{c}\text { OGCT Ratio } \\
\text { (Element:Fe) }\end{array}$ & $\begin{array}{c}\text { RCT Ratio } \\
\text { (Element:Fe) }\end{array}$ & $\begin{array}{c}\text { May 2004 } \\
\text { SB3 Ratio } \\
\text { (Element:Fe) }\end{array}$ \\
\hline & & & & \\
\hline $\mathrm{Al}$ & $\mathbf{2 . 9 5 E - 0 1}$ & $1.05 \mathrm{E}-01$ & $\mathbf{3 . 6 4 E - 0 1}$ & $\mathbf{3 . 1 1 E - 0 1}$ \\
\hline $\mathrm{B}$ & $2.79 \mathrm{E}-01$ & $2.23 \mathrm{E}-02$ & $2.60 \mathrm{E}-02$ & $5.14 \mathrm{E}-04$ \\
\hline $\mathrm{Fe}$ & $1.00 \mathrm{E}+00$ & $1.00 \mathrm{E}+00$ & $1.00 \mathrm{E}+00$ & $1.00 \mathrm{E}+00$ \\
\hline $\mathrm{Li}$ & $<2 \mathrm{E}-01$ & $9.82 \mathrm{E}-03$ & $5.61 \mathrm{E}-02$ & $2.06 \mathrm{E}-03$ \\
\hline $\mathrm{Mg}$ & $2.30 \mathrm{E}-01$ & $5.61 \mathrm{E}-02$ & $\mathbf{8 . 7 2 E - 0 2}$ & $\mathbf{8 . 5 9 E}-02$ \\
\hline $\mathrm{Mn}$ & $4.75 \mathrm{E}-01$ & $1.19 \mathrm{E}-01$ & $\mathbf{2 . 1 8 E - 0 1}$ & $\mathbf{2 . 0 3 E - 0 1}$ \\
\hline $\mathrm{Na}$ & $2.13 \mathrm{E}+00$ & $1.64 \mathrm{E}-01$ & $1.47 \mathrm{E}+01$ & $6.20 \mathrm{E}-01$ \\
\hline $\mathrm{Ni}$ & $1.30 \mathrm{E}-01$ & $5.22 \mathrm{E}-02$ & $\mathbf{5 . 6 3 E - 0 2}$ & $\mathbf{5 . 6 1 E - 0 2}$ \\
\hline $\mathrm{Si}$ & $5.57 \mathrm{E}+02$ & $1.66 \mathrm{E}-01$ & $2.41 \mathrm{E}-01$ & $2.06 \mathrm{E}-02$ \\
\hline $\mathrm{U}$ & $7.87 \mathrm{E}-01$ & $6.74 \mathrm{E}-02$ & $\mathbf{3 . 1 0 E}-01$ & $\mathbf{3 . 6 0 E - 0 1}$ \\
\hline
\end{tabular}

Indicates ratios agree for a particular element

The only element for the SMECT sample that matches the SB3 ratio, outside of Fe, is the Al. Since the SMECT receives condensate from the SRAT and SME vessels, it is expected that minor amounts of slurry could be entrained in the condensate. The only time the SMECT ratios would agree with all of the SB3 sludge ratios is if a process upset occurred carrying a significant amount of sludge over to the SMECT vessel.

The ratios for the elements in Table 3 for the OGCT sample do not match the SB3 composition. However, the elements reported are consistent with the elements previously reported by C.M. Jantzen for a nonradioactive sample of the Condensate Tank for the Scale Glass Melter ${ }^{1}$. That sample was split into two samples, a solid sample and supernate sample. The solids were analyzed by Scanning Electron Microscopy (SEM) and the supernate was analyzed by ICP-ES. The major elements reported for the supernate fraction consisted of $\mathrm{Na}, \mathrm{B}$, and $\mathrm{Ca}$. The solid fraction of the sample contained deposits that were rich in $\mathrm{Si}$, and spinel forming elements ( $\mathrm{Al}, \mathrm{Fe}, \mathrm{Mn}$, and $\mathrm{Ni}$ ). C.M. Jantzen concluded that deposits containing entrained spinel and frit were being carried from the melter plenum to the condensate tank. The elements reported for the OGCT sample could also be due to spinels and frit being carried from the melter plenum as observed in the C.M. Jantzen sample. SEM analysis was not performed to confirm this conclusion for the OGCT sample.

Five of the nine ratios for this RCT sample agreed with the ratios for the SB3 sample. The elements were $\mathrm{Al}, \mathrm{Mg}, \mathrm{Mn}, \mathrm{Ni}$ and $\mathrm{U}$. This agreement suggests that the primary component in this RCT sample is indeed due to SB3 sludge. 


\subsection{CONCLUSIONS}

Several conclusions and observations were made from the data presented in Section 3.0. A list of these conclusions and observations are presented below.

- The OGCT and RCT samples had visible brown solids, and the SMECT samples had no visible solids. The solids in the OGCT sample appeared to be made up of fine particulates and settled very slowly when agitation of the sample was stopped. The solids in the RCT sample appeared to be fine as well, but settled quickly.

- The dried weight percent total solids (dried at $110^{\circ} \mathrm{C}$ ) for the OGCT and SMECT samples were very low; 0.44 and $<1 \mathrm{E}-03$ weight percent, respectively. The dried weight percent total solids for the RCT sample were also low; 1.88 weight percent.

- The results for the weight percent dissolved solids for the OGCT and SMECT samples indicate that there were no dissolved solids. For the OGCT sample, the total solids are considered all insoluble solids.

- The dried weight percent dissolved solids for the RCT sample were 1.73 weight percent. In the case of the RCT sample vs. the OGCT sample, the majority of solids are soluble vs. insoluble.

- The $\mathrm{pH}$ of the OGCT, RCT, and SMECT samples were measured and found to be 2.3, 12.6, and 1.4 , respectively.

- The major elements found in the dried solids of the OGCT sample were Fe, Si, Na, Mn, Al, and $\mathrm{U}$. This is consistent with the results previously published by C.M. Jantzen ${ }^{1}$ for a Scaled Glass Melter Off-Gas Condensate Tank sample.

- The composition of the OGCT should be dependent on the feed being fed to the melter, however for this sample the relative composition only agreed for $\mathrm{Al}$ and Fe. The difference seen in the relative amounts of the elements reported for the OGCT sample could be due to spinels being carried from the melter plenum as observed in the C.M. Jantzen sample. Scanning Electron Microscopy (SEM) was not performed to confirm this conclusion for the OGCT sample.

- The major elements found in the dried solids of the RCT sample were $\mathrm{Na}, \mathrm{Fe}, \mathrm{Al}, \mathrm{U}, \mathrm{Si}$, and Mn. The relative composition for the RCT agrees reasonably well with the relative composition of Sludge Batch 3. This agreement suggests that the primary component in this RCT sample is indeed due to SB3 sludge.

- The high Na seen in the RCT sample is due to the neutralization of the RCT prior to the transfer of these contents back to the Tank Farm.

- The radioactive data for the OGCT and RCT samples agree well, upon converting the data to a micro-curie per milliliter slurry basis. This suggests that the radioactivity in this RCT sample is due to the contribution from the OGCT

- The major elements found in the SMECT samples were Si, Hg, Al, Na, and U. Since the SMECT receives condensate from the SRAT and SME vessels, it is expected that minor amounts of sludge components such as $\mathrm{Al}, \mathrm{Na}$, and $\mathrm{U}$ could be entrained in the condensate. 
- The amount of Si present in the SMECT samples is probably from the antifoam additions and the $\mathrm{Hg}$ is from the steam stripping operations during the SRAT cycle.

\subsection{RECOMMENDATIONS/PATH FORWARD}

- Since the composition of the samples is dependant on the incoming streams to the individual tanks, they are likely to change over time depending on the Sludge Batch being processed. It is recommended that this data be treated as a snapshot in time, and the composition provided for each tank be bounded for the upcoming experimental work and computer modeling.

- Complete the analyses for the DWTT samples on hand and document the composition. 


\subsection{REFERENCES}

${ }^{1}$ C.M. Jantzen, “Glass Melter Off-Gas System Pluggages: Cause, Significance, and Remediation (U), WSRC-TR-90-205, Rev.0, March 1991.

${ }^{2}$ D.P. Lambert, C.D. Barnes, S.G. Phillips, “DWPF Recycle Evaporator - Feasibility Study (U)”, WSRCRP-2001-01101, Rev.0, January 18, 2002.

${ }^{3}$ W.R. Wilmarth, "Results of Aluminosilicate Formation Testing”, WSRC-TR-2001-00330, September 11, 2001.

${ }^{4}$ SRS Need Title, "Provide Alternative Processing and/or Concentration Methods for DWPF Recycle Aqueous Streams”, ID No. SR00-2033, November 2000.

${ }^{5}$ S.G. Phillips, "Process Development for DWPF Recycle Acid Evaporator”, HLW/DWPF/TTR-04-0020, Rev. 0.

${ }^{6}$ T.L. Fellinger “TTQAP Process Development for the DWPF Recycle Acid Evaporator (U)”, WSRC-RP2004-00589, 8/11/2004.

${ }^{7}$ N.E. Bibler and T.B. Edwards, "Composition of Condensate Samples from the Sludge Receipt and Adjustment Tank and the Slurry Mix Evaporator in the DWPF”, WSRC-TR-2004-00575, August 2004.

${ }^{8}$ J.C. Marek, “Correction Factor for Soluble and Insoluble Solids (U)”, SRTC-PTD-92-0040, August 28, 1992.

${ }^{9}$ J.M. Pareizs, T.L. Fellinger, D.R. Click, “Characterization of the March 2004 Tank 40 (Sludge Batch 3) Dip Samples (U)”, WSRC-TR-2004-00208, Rev. 0, May 2004. 


\section{APPENDIX A}

Table A-1 - Averages, Standard Deviations and Percent Relative Standard Deviations for the OGCT Data

\begin{tabular}{|c|c|c|c|c|}
\hline DATA FOR OGCT & Analyte & Average & STDEV & \%RSD \\
\hline \multirow[t]{6}{*}{ Wt.\% Solids and Density } & Wt.\% Dissolved Solids of Supernate & - & - & - \\
\hline & Wt. \% Total Solids of Slurry & 4.40E-01 & - & - \\
\hline & Wt.\% Insoluble Solids & $4.40 \mathrm{E}-01$ & - & - \\
\hline & Wt.\% Soluble Solids & - & - & - \\
\hline & Slurry Density, g/mL & $1.02 \mathrm{E}+00$ & 8.30E-03 & 8.11E-01 \\
\hline & Supernate Density, g/mL & 9.85E-01 & 3.62E-03 & 3.67E-01 \\
\hline \multirow[t]{4}{*}{ Wet Chem } & Total Carbon, mg/L & $1 \mathrm{E}+02$ & $2 \mathrm{E}+00$ & $2 \mathrm{E}+00$ \\
\hline & Total Organic Carbon, mg/L & $1 \mathrm{E}+02$ & $2 \mathrm{E}+00$ & $2 \mathrm{E}+00$ \\
\hline & Total Inorganic Carbon, mg/L & $1 \mathrm{E}+02$ & $2 \mathrm{E}+00$ & $2 \mathrm{E}+00$ \\
\hline & Particle Size & - & - & - \\
\hline \multirow[t]{2}{*}{ Titration } & Equivalents Required for $\mathrm{pH}=7$ & 1.99E-02 & $9.55 \mathrm{E}-04$ & $4.79 \mathrm{E}+00$ \\
\hline & $\mathrm{pH}$ & $2.26 \mathrm{E}+00$ & 7.07E-02 & $3.13 \mathrm{E}+00$ \\
\hline \multirow[t]{8}{*}{ Anions (mg/L of supernate) } & Chloride & $5.09 \mathrm{E}+00$ & $7.76 \mathrm{E}-01$ & $1.52 \mathrm{E}+01$ \\
\hline & Formate & $1.39 \mathrm{E}+01$ & $8.00 \mathrm{E}-02$ & $5.76 \mathrm{E}-01$ \\
\hline & Fluoride & $1.94 \mathrm{E}+01$ & $1.29 \mathrm{E}+00$ & $6.61 \mathrm{E}+00$ \\
\hline & Nitrate & $1.59 \mathrm{E}+03$ & $1.98 \mathrm{E}+01$ & $1.24 \mathrm{E}+00$ \\
\hline & Nitrite & $1.39 \mathrm{E}+01$ & 8.00E-02 & $5.76 \mathrm{E}-01$ \\
\hline & Oxalate & $1.39 \mathrm{E}+01$ & $8.00 \mathrm{E}-02$ & $5.76 \mathrm{E}-01$ \\
\hline & Phosphate & $1.39 \mathrm{E}+01$ & 8.00E-02 & $5.76 \mathrm{E}-01$ \\
\hline & Sulfate & $6.11 \mathrm{E}+01$ & $8.19 \mathrm{E}+00$ & $1.34 \mathrm{E}+01$ \\
\hline IC-Cations (mg/L of supernate) & Ammonium & $1.39 \mathrm{E}+00$ & 8.00E-03 & $5.76 \mathrm{E}-01$ \\
\hline \multirow[t]{4}{*}{ AA Results (wt.\% dried sludge solids) } & $\mathrm{Hg}$ & 3.64E-02 & 8.17E-04 & $2.24 \mathrm{E}+00$ \\
\hline & As & $6 \mathrm{E}-03$ & - & - \\
\hline & $\mathrm{K}$ & $1.80 \mathrm{E}-02$ & $1.42 \mathrm{E}-03$ & $7.87 \mathrm{E}+00$ \\
\hline & Se & $6 \mathrm{E}-03$ & - & - \\
\hline \multirow[t]{15}{*}{ ICP-ES (wt.\% dried sludge solids) } & $\mathrm{Ag}$ & 1.34E-02 & $6.73 \mathrm{E}-04$ & $5.01 \mathrm{E}+00$ \\
\hline & $\mathrm{Al}$ & $2.36 \mathrm{E}+00$ & $1.10 \mathrm{E}-01$ & $4.66 \mathrm{E}+00$ \\
\hline & $\mathrm{B}$ & 5.03E-01 & $2.94 \mathrm{E}-02$ & $5.84 \mathrm{E}+00$ \\
\hline & $\mathrm{Ba}$ & $3.08 \mathrm{E}-02$ & 6.17E-04 & $2.01 \mathrm{E}+00$ \\
\hline & $\mathrm{Be}$ & $2.85 \mathrm{E}-04$ & 3.14E-06 & $1.10 \mathrm{E}+00$ \\
\hline & $\mathrm{Ca}$ & 5.13E-01 & $2.37 \mathrm{E}-02$ & $4.63 \mathrm{E}+00$ \\
\hline & Cd & $3.24 \mathrm{E}-01$ & $1.08 \mathrm{E}-02$ & $3.33 \mathrm{E}+00$ \\
\hline & $\mathrm{Ce}$ & 4.84E-02 & 3.73E-03 & $7.69 \mathrm{E}+00$ \\
\hline & $\mathrm{Cr}$ & 8.29E-02 & $1.97 \mathrm{E}-03$ & $2.38 \mathrm{E}+00$ \\
\hline & $\mathrm{Cu}$ & $2.74 \mathrm{E}-02$ & 4.70E-04 & $1.72 \mathrm{E}+00$ \\
\hline & $\mathrm{Fe}$ & $2.26 \mathrm{E}+01$ & $2.62 \mathrm{E}-01$ & $1.16 \mathrm{E}+00$ \\
\hline & Gd & $2.02 \mathrm{E}-02$ & 8.05E-04 & $3.98 \mathrm{E}+00$ \\
\hline & $\mathrm{La}$ & $1.75 \mathrm{E}-02$ & $1.23 \mathrm{E}-03$ & $7.04 \mathrm{E}+00$ \\
\hline & $\mathrm{Li}$ & $2.21 \mathrm{E}-01$ & 4.67E-03 & $2.11 \mathrm{E}+00$ \\
\hline & $\mathrm{Mg}$ & $1.27 \mathrm{E}+00$ & 1.66E-02 & $1.31 \mathrm{E}+00$ \\
\hline
\end{tabular}


WSRC-TR-2004-00577

Revision 0

\begin{tabular}{|c|c|c|c|c|}
\hline DATA FOR OGCT & Analyte & Average & STDEV & \%RSD \\
\hline & $\mathrm{Mn}$ & $2.69 \mathrm{E}+00$ & 3.63E-02 & $1.35 \mathrm{E}+00$ \\
\hline & Mo & 7.76E-02 & 6.20E-03 & $7.99 \mathrm{E}+00$ \\
\hline & $\mathrm{Na}$ & $3.71 \mathrm{E}+00$ & $2.28 \mathrm{E}-01$ & $6.16 \mathrm{E}+00$ \\
\hline & $\mathrm{Ni}$ & $1.18 \mathrm{E}+00$ & $1.27 \mathrm{E}-02$ & $1.08 \mathrm{E}+00$ \\
\hline & $\bar{P}$ & 3.35E-01 & 2.91E-03 & $8.68 \mathrm{E}-01$ \\
\hline & $\mathrm{Pb}$ & 4.16E-02 & $1.86 \mathrm{E}-03$ & $4.49 \mathrm{E}+00$ \\
\hline & $\mathrm{S}$ & $4.73 \mathrm{E}-01$ & $3.87 \mathrm{E}-02$ & $8.17 \mathrm{E}+00$ \\
\hline & $\mathrm{Sb}$ & 7.51E-02 & 3.29E-03 & $4.38 \mathrm{E}+00$ \\
\hline & $\mathrm{Si}$ & $3.74 \mathrm{E}+00$ & $1.54 \mathrm{E}-02$ & 4.13E-01 \\
\hline & Sn & 1.19E-01 & 6.06E-03 & $5.10 \mathrm{E}+00$ \\
\hline & $\mathrm{Sr}$ & $1.33 \mathrm{E}-01$ & $6.38 \mathrm{E}-03$ & $4.79 \mathrm{E}+00$ \\
\hline & $\mathrm{Ti}$ & $1.55 \mathrm{E}-02$ & 1.93E-04 & $1.25 \mathrm{E}+00$ \\
\hline & $\bar{U}$ & $1.52 \mathrm{E}+00$ & $1.12 \mathrm{E}-01$ & $7.36 \mathrm{E}+00$ \\
\hline & $\mathrm{V}$ & $2.90 \mathrm{E}-02$ & - & - \\
\hline & $\mathrm{Zn}$ & $3.82 \mathrm{E}-02$ & $1.17 \mathrm{E}-03$ & $3.08 \mathrm{E}+00$ \\
\hline & $\mathrm{Zr}$ & $9.48 \mathrm{E}-02$ & $1.29 \mathrm{E}-03$ & $1.36 \mathrm{E}+00$ \\
\hline \multirow[t]{11}{*}{ ICP-MS Results (wt. \% dried sludge solids) } & $\mathrm{Ru}$ & $3.42 \mathrm{E}-02$ & - & - \\
\hline & $\mathrm{Rh}$ & 6.19E-03 & - & - \\
\hline & $\mathrm{Pd}$ & 1.23E-03 & - & - \\
\hline & $\mathrm{Ag}$ & 9.73E-03 & - & - \\
\hline & $\mathrm{Cd}$ & $3.50 \mathrm{E}-01$ & - & - \\
\hline & $\mathrm{U}$ & $1.32 \mathrm{E}+00$ & - & - \\
\hline & Pu-239 & $1.46 \mathrm{E}-02$ & $4.72 \mathrm{E}-04$ & $3.23 \mathrm{E}+00$ \\
\hline & Pu-240 & $1.36 \mathrm{E}-03$ & 3.90E-05 & $2.86 \mathrm{E}+00$ \\
\hline & Pu-242 & 6.92E-05 & $1.36 \mathrm{E}-05$ & $1.97 \mathrm{E}+01$ \\
\hline & Tc-99 & $2.83 \mathrm{E}-03$ & 1.79E-04 & $6.33 \mathrm{E}+00$ \\
\hline & La-139 & $1.42 \mathrm{E}-02$ & $3.26 \mathrm{E}-04$ & $2.29 \mathrm{E}+00$ \\
\hline \multirow[t]{10}{*}{ Radioactivity ( $\mu \mathrm{Ci} / \mathrm{g}$ of dried sludge solids) } & Total Alpha & $9.65 \mathrm{E}+01$ & $8.78 \mathrm{E}+00$ & $9.09 \mathrm{E}+00$ \\
\hline & Total Beta & $4.20 \mathrm{E}+03$ & $1.63 \mathrm{E}+02$ & $3.89 \mathrm{E}+00$ \\
\hline & Total Gamma & $1.84 \mathrm{E}+02$ & - & - \\
\hline & Co-60 & $1.95 \mathrm{E}+00$ & 1.12E-01 & $5.72 \mathrm{E}+00$ \\
\hline & Ru-106 & $3.43 \mathrm{E}+00$ & $1.17 \mathrm{E}+00$ & $3.40 \mathrm{E}+01$ \\
\hline & Sb-125 & $2.62 \mathrm{E}+00$ & $1.12 \mathrm{E}+00$ & $4.26 \mathrm{E}+01$ \\
\hline & Cs-137 & $1.62 \mathrm{E}+02$ & $8.53 \mathrm{E}+00$ & $5.25 \mathrm{E}+00$ \\
\hline & Eu-154 & $3.06 \mathrm{E}+00$ & 2.04E-01 & $6.65 \mathrm{E}+00$ \\
\hline & Am-241 & $1.06 \mathrm{E}+01$ & $1.73 \mathrm{E}+00$ & $1.63 \mathrm{E}+01$ \\
\hline & Total beta-gamma, , $\mu \mathrm{Ci} / \mathrm{g}$ & $4.38 \mathrm{E}+03$ & - & - \\
\hline
\end{tabular}

Shaded areas indicate less than values. 
Table A-2 - Averages, Standard Deviations and Percent Relative Standard Deviations for the RCT Data

\begin{tabular}{|c|c|c|c|c|}
\hline DATA FOR RCT & Analyte & Average & STDEV. & \%RSD \\
\hline \multirow[t]{6}{*}{ Wt.\% Solids and Density } & Wt.\% Dissolved Solids of Supernate & $1.73 \mathrm{E}+00$ & 1.16E-02 & 6.74E-01 \\
\hline & Wt. \% Total Solids of Slurry & $1.88 \mathrm{E}+00$ & 1.87E-02 & 9.95E-01 \\
\hline & Wt.\% Insoluble Solids & $1.55 \mathrm{E}-01$ & $1.97 \mathrm{E}-02$ & $1.27 \mathrm{E}+01$ \\
\hline & Wt.\% Soluble Solids & $1.72 \mathrm{E}+00$ & $1.17 \mathrm{E}-02$ & 6.81E-01 \\
\hline & Slurry Density, g/mL & $1.02 \mathrm{E}+00$ & $7.25 \mathrm{E}-03$ & 7.12E-01 \\
\hline & Supernate Density, g/mL & $1.01 \mathrm{E}+00$ & $2.87 \mathrm{E}-03$ & $2.83 \mathrm{E}-01$ \\
\hline \multirow[t]{4}{*}{ Wet Chem } & Total Carbon, mg/L & $1.91 \mathrm{E}+02$ & $5.85 \mathrm{E}+00$ & $3.06 \mathrm{E}+00$ \\
\hline & Total Organic Carbon, mg/L & $1.43 \mathrm{E}+02$ & $1.02 \mathrm{E}+00$ & 7.12E-01 \\
\hline & Total Inorganic Carbon, mg/L & $5 E+01$ & $5 E+00$ & $1 \mathrm{E}+01$ \\
\hline & Particle Size & - & - & - \\
\hline \multirow[t]{2}{*}{ Titration } & Equivalents Required for $\mathrm{pH}=7$ & $7.76 \mathrm{E}-02$ & 4.10E-03 & $5.29 \mathrm{E}+00$ \\
\hline & $\mathrm{pH}$ & $1.26 \mathrm{E}+01$ & $7.07 \mathrm{E}-03$ & 5.63E-02 \\
\hline \multirow[t]{8}{*}{ Anions (mg/L of supernate) } & Chloride & $3 \mathrm{E}+01$ & $4 \mathrm{E}-02$ & $1 \mathrm{E}-01$ \\
\hline & Formate & $3.10 \mathrm{E}+02$ & $1.34 \mathrm{E}+01$ & $4.31 \mathrm{E}+00$ \\
\hline & Fluoride & $3 \mathrm{E}+01$ & 4E-02 & $1 \mathrm{E}-01$ \\
\hline & Nitrate & $4.08 \mathrm{E}+03$ & $1.56 \mathrm{E}+02$ & $3.81 \mathrm{E}+00$ \\
\hline & Nitrite & $4.74 \mathrm{E}+03$ & $1.97 \mathrm{E}+02$ & $4.16 \mathrm{E}+00$ \\
\hline & Oxalate & $1.4 \mathrm{E}+02$ & $2.0 \mathrm{E}-01$ & $1.4 \mathrm{E}-01$ \\
\hline & Phosphate & $1.4 \mathrm{E}+02$ & $2.0 \mathrm{E}-01$ & $1.4 \mathrm{E}-01$ \\
\hline & Sulfate & $4.80 \mathrm{E}+01$ & $2.47 \mathrm{E}+00$ & $5.15 \mathrm{E}+00$ \\
\hline IC-Cations (mg/L of supernate) & Ammonium & $1.41 \mathrm{E}+01$ & $2.01 \mathrm{E}-02$ & 1.43E-01 \\
\hline \multirow[t]{4}{*}{ AA Results (wt.\% dried sludge solids) } & $\mathrm{Hg}$ & $8.58 \mathrm{E}-02$ & $1.12 \mathrm{E}-02$ & $1.31 \mathrm{E}+01$ \\
\hline & As & $3 \mathrm{E}-03$ & - & - \\
\hline & $\mathrm{K}$ & $3.68 \mathrm{E}-02$ & 5.03E-03 & $1.37 \mathrm{E}+01$ \\
\hline & Se & $3 \mathrm{E}-03$ & - & - \\
\hline \multirow[t]{18}{*}{ ICP-ES (wt.\% dried sludge solids) } & $\mathrm{Ag}$ & $2.94 \mathrm{E}-03$ & 4.84E-04 & $1.65 \mathrm{E}+01$ \\
\hline & $\mathrm{Al}$ & 6.73E-01 & $6.26 \mathrm{E}-03$ & 9.30E-01 \\
\hline & $\mathrm{B}$ & 4.81E-02 & 1.65E-03 & $3.43 \mathrm{E}+00$ \\
\hline & $\mathrm{Ba}$ & 5.53E-03 & $1.11 \mathrm{E}-03$ & $2.01 \mathrm{E}+01$ \\
\hline & $\mathrm{Be}$ & 4.15E-05 & $1.03 \mathrm{E}-06$ & $2.49 \mathrm{E}+00$ \\
\hline & $\mathrm{Ca}$ & 3.00E-01 & 7.61E-03 & $2.54 \mathrm{E}+00$ \\
\hline & $\mathrm{Cd}$ & $3.14 \mathrm{E}-02$ & $6.40 \mathrm{E}-03$ & $2.04 \mathrm{E}+01$ \\
\hline & $\mathrm{Ce}$ & $1.42 \mathrm{E}-02$ & $1.88 \mathrm{E}-03$ & $1.32 \mathrm{E}+01$ \\
\hline & $\mathrm{Cr}$ & $1.62 \mathrm{E}-02$ & $6.10 \mathrm{E}-04$ & $3.78 \mathrm{E}+00$ \\
\hline & $\mathrm{Cu}$ & $3.11 \mathrm{E}-03$ & $6.95 \mathrm{E}-04$ & $2.24 \mathrm{E}+01$ \\
\hline & $\mathrm{Fe}$ & $1.85 \mathrm{E}+00$ & $4.16 \mathrm{E}-02$ & $2.25 \mathrm{E}+00$ \\
\hline & Gd & $4.98 \mathrm{E}-03$ & $9.23 \mathrm{E}-04$ & $1.85 \mathrm{E}+01$ \\
\hline & $\mathrm{La}$ & $5.16 \mathrm{E}-03$ & $1.05 \mathrm{E}-03$ & $2.04 \mathrm{E}+01$ \\
\hline & $\mathrm{Li}$ & $1.04 \mathrm{E}-01$ & $2.08 \mathrm{E}-02$ & $2.01 \mathrm{E}+01$ \\
\hline & $\mathrm{Mg}$ & $1.61 \mathrm{E}-01$ & 3.23E-03 & $2.00 \mathrm{E}+00$ \\
\hline & Mn & 4.03E-01 & $1.06 \mathrm{E}-02$ & $2.63 \mathrm{E}+00$ \\
\hline & Mo & $9.71 \mathrm{E}-03$ & $1.86 \mathrm{E}-04$ & $1.92 \mathrm{E}+00$ \\
\hline & $\mathrm{Na}$ & $2.71 \mathrm{E}+01$ & 2.93E-01 & $1.08 \mathrm{E}+00$ \\
\hline
\end{tabular}


WSRC-TR-2004-00577

Revision 0

\begin{tabular}{|c|c|c|c|c|}
\hline DATA FOR RCT & Analyte & Average & STDEV. & \%RSD \\
\hline & $\mathrm{Ni}$ & $1.04 \mathrm{E}-01$ & $2.16 \mathrm{E}-02$ & $2.08 \mathrm{E}+01$ \\
\hline & $\mathrm{P}$ & 4.97E-02 & 7.69E-03 & $1.55 \mathrm{E}+01$ \\
\hline & $\mathrm{Pb}$ & $1.5 \mathrm{E}-02$ & $3.7 \mathrm{E}-04$ & $2.5 \mathrm{E}+00$ \\
\hline & $\mathrm{S}$ & $9.11 \mathrm{E}-02$ & $6.99 \mathrm{E}-03$ & $7.67 \mathrm{E}+00$ \\
\hline & $\mathrm{Sb}$ & $8.40 \mathrm{E}-03$ & $1.45 \mathrm{E}-03$ & $1.73 \mathrm{E}+01$ \\
\hline & $\mathrm{Si}$ & 4.45E-01 & 7.22E-02 & $1.62 \mathrm{E}+01$ \\
\hline & Sn & 1.47E-02 & 3.07E-03 & $2.09 \mathrm{E}+01$ \\
\hline & $\mathrm{Sr}$ & $4.43 \mathrm{E}-02$ & $8.97 \mathrm{E}-03$ & $2.03 \mathrm{E}+01$ \\
\hline & $\mathrm{Ti}$ & $1.96 \mathrm{E}-03$ & 4.75E-04 & $2.43 \mathrm{E}+01$ \\
\hline & $\mathrm{U}$ & 5.73E-01 & 2.35E-02 & $4.10 \mathrm{E}+00$ \\
\hline & $\mathrm{V}$ & $4 \mathrm{E}-03$ & 9E-05 & $2 \mathrm{E}+00$ \\
\hline & Zn & $4.85 \mathrm{E}-03$ & $7.94 \mathrm{E}-04$ & $1.64 \mathrm{E}+01$ \\
\hline & $\mathrm{Zr}$ & $8.44 \mathrm{E}-03$ & $1.83 \mathrm{E}-03$ & $2.17 \mathrm{E}+01$ \\
\hline \multirow[t]{12}{*}{ ICP-MS Results (wt.\% dried sludge solids) } & $\mathrm{Ru}$ & $1.77 \mathrm{E}-03$ & - & - \\
\hline & $\mathrm{Rh}$ & 3.45E-04 & - & - \\
\hline & Pd & 5.67E-05 & - & - \\
\hline & $\mathrm{Ag}$ & $5.76 \mathrm{E}-04$ & - & - \\
\hline & $\mathrm{Cd}$ & $1.51 \mathrm{E}-02$ & & \\
\hline & $\mathrm{Hg}$ & $8.82 \mathrm{E}-03$ & & \\
\hline & $\mathrm{U}$ & $3.11 \mathrm{E}-01$ & & \\
\hline & Pu-239 & 1.03E-03 & $2.15 \mathrm{E}-04$ & $2.09 \mathrm{E}+01$ \\
\hline & $\mathrm{Pu}-240$ & 9.42E-05 & $1.92 \mathrm{E}-05$ & $2.04 \mathrm{E}+01$ \\
\hline & $\mathrm{Pu}-242$ & - & - & - \\
\hline & Tc-99 & 1.59E-04 & $6.47 \mathrm{E}-06$ & $4.06 \mathrm{E}+00$ \\
\hline & La-139 & $1.28 \mathrm{E}-03$ & 2.63E-04 & $2.06 \mathrm{E}+01$ \\
\hline \multirow[t]{10}{*}{ Radioactivity ( $\mu \mathrm{Ci} / \mathrm{g}$ of dried sludge solids) } & Total Alpha & $2.59 \mathrm{E}+01$ & $1.59 \mathrm{E}+00$ & $6.12 \mathrm{E}+00$ \\
\hline & Total Beta & $1.34 \mathrm{E}+03$ & $8.40 \mathrm{E}+01$ & $6.25 \mathrm{E}+00$ \\
\hline & Total Gamma & $5.96 \mathrm{E}+01$ & - & - \\
\hline & Co-60 & $2.09 \mathrm{E}-01$ & $2.39 \mathrm{E}-02$ & $1.15 \mathrm{E}+01$ \\
\hline & Ru-106 & $1 \mathrm{E}+00$ & 2E-01 & $1 \mathrm{E}+01$ \\
\hline & Sb-125 & $1 \mathrm{E}+00$ & $5 \mathrm{E}-01$ & $5 \mathrm{E}+01$ \\
\hline & Cs-137 & $5.41 \mathrm{E}+01$ & $1.53 \mathrm{E}+01$ & $2.82 \mathrm{E}+01$ \\
\hline & Eu-154 & 9.38E-01 & $8.56 \mathrm{E}-02$ & $9.13 \mathrm{E}+00$ \\
\hline & Am-241 & $1.95 \mathrm{E}+00$ & $3.27 \mathrm{E}-01$ & $1.68 \mathrm{E}+01$ \\
\hline & Total beta-gamma, , $\mu \mathrm{Ci} / \mathrm{g}$ & $1.40 \mathrm{E}+03$ & - & - \\
\hline
\end{tabular}

Shaded areas indicate less than values. 
Figure A - 1 Titration Curve for the OGCT Samples

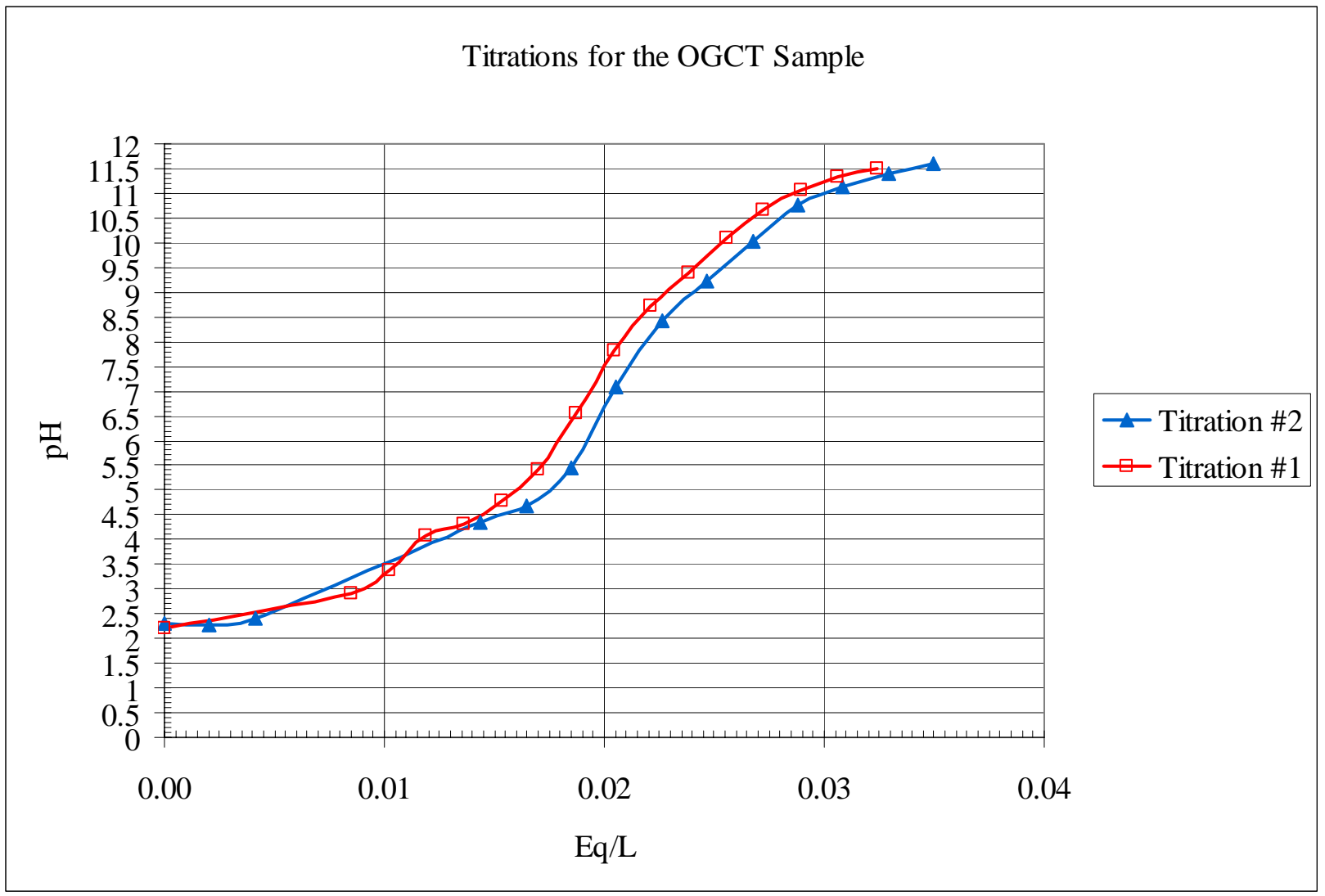


WSRC-TR-2004-00577

Revision 0

Figure A - 2 Titration Curve for the RCT Samples

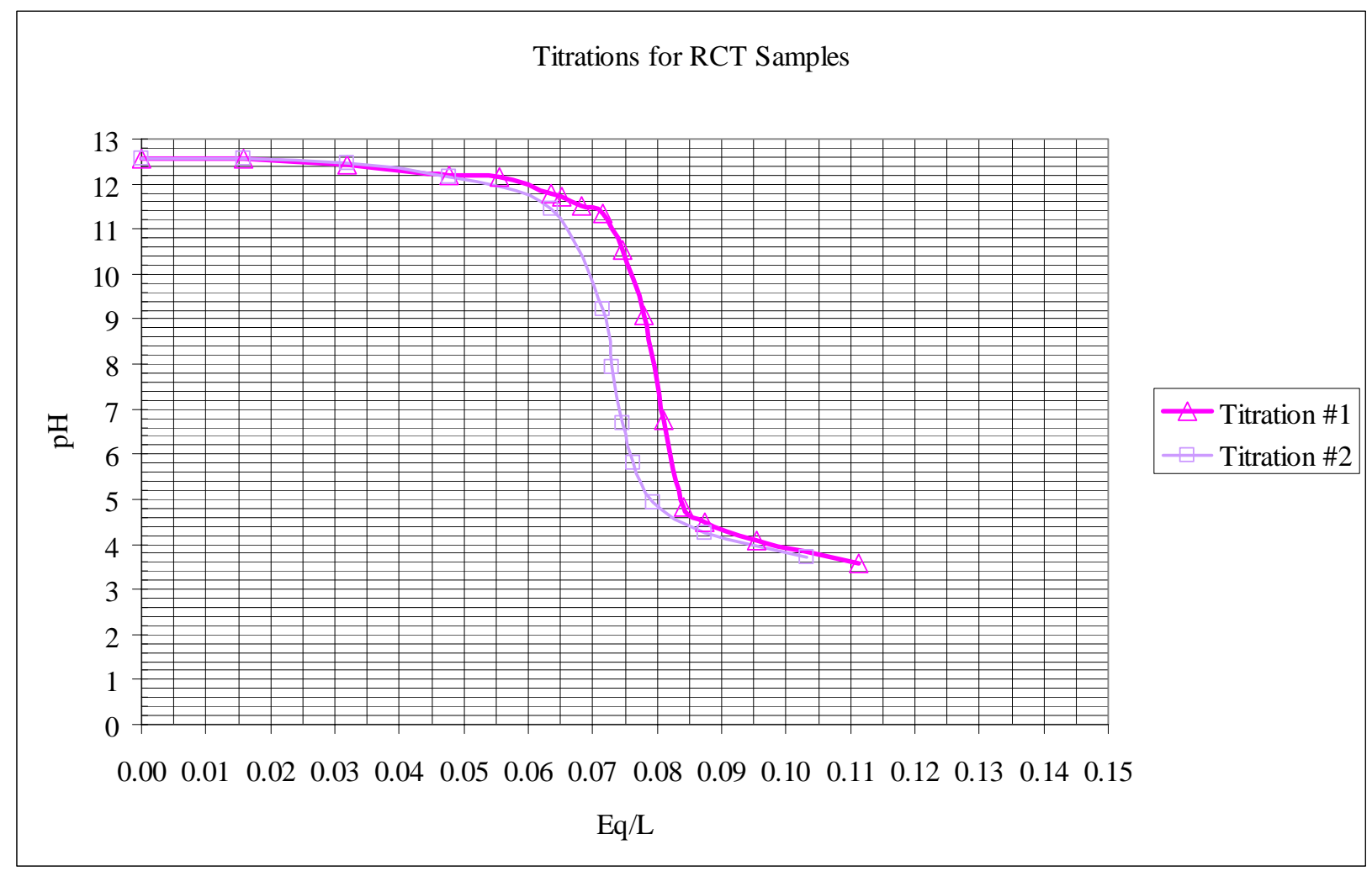

